\title{
Erratum to: Venous gas embolism as a predictive tool for improving CNS decompression safety
}

\author{
A. Møllerløkken - S. E. Gaustad - M. B. Havnes • \\ C. R. Gutvik · A. Hjelde · U. Wisløff · A. O. Brubakk
}

Published online: 4 August 2011

(C) Springer-Verlag 2011

\section{Erratum to: Eur J Appl Physiol}

\section{DOI 10.1007/s00421-011-1998-9}

An incorrect citation was included in the original publication:

Vince RV, Chrismas B, Midgley AW, McNaughton LR, Madden LA (2009) Hypoxia mediated release of endothelial microparticles and increased association of S100A12 with circulating neutrophils. Oxid Med Cell Longev 2:2-6

The correct reference should be:

Vince RV, McNaughton LR, Taylor L, Midgley AW, Laden G, Madden LA (2009) Release of VCAM-1 associated endothelial microparticles following simulated SCUBA dives. Eur J Appl Physiol 105:507-513

The online version of the original article can be found under doi:10.1007/s00421-011-1998-9.

\footnotetext{
A. Møllerløkken $(\bowtie) \cdot$ S. E. Gaustad · M. B. Havnes C. R. Gutvik · A. Hjelde - U. Wisløff · A. O. Brubakk Baromedical and Environmental Physiology Group, Department of Circulation and Medical Imaging, Norwegian University of Science and Technology, Medisinsk teknisk forskningssenter,

Olav Kyrres gt 9, 7489 Trondheim, Norway

e-mail: andreas.mollerlokken@ntnu.no
} 